\title{
Genetic population structure of four hydrothermal vent shrimp species (Alvinocarididae) in the Okinawa Trough, Northwest Pacific
}

\author{
Takuya Yahagi ${ }^{1,2, *}$, Hiromi Watanabe ${ }^{3}$, Jun-ichiro Ishibashi ${ }^{4}$, Shigeaki Kojima ${ }^{1,2}$ \\ ${ }^{1}$ Atmosphere and Ocean Research Institute, The University of Tokyo, 5-1-5 Kashiwanoha, Kashiwa, Chiba 277-8564, Japan \\ ${ }^{2}$ Graduate School of Frontier Sciences, The University of Tokyo, 5-1-5 Kashiwanoha, Kashiwa, Chiba 277-8561, Japan \\ ${ }^{3}$ Japan Agency for Marine-Earth Science and Technology, 2-15 Natsushima-cho, Yokosuka, Kanagawa 237-0061, Japan \\ ${ }^{4}$ Department of Earth and Planetary Sciences, Faculty of Sciences, Kyushu University, 6-10-1 Hakozaki, Higashi-ku, \\ Fukuoka 812-8581, Japan
}

\begin{abstract}
Understanding the formative factors of connectivity among deep-sea chemosynthetic communities may clarify the biogeographic mechanisms that facilitate the establishment and development of vent/seep fauna. This study identified interspecific differences in the geographical distribution and genetic population structure of 4 alvinocaridid shrimp species inhabiting hydrothermal vents in the Okinawa Trough, Northwest Pacific. Shinkaicaris leurokolos populations were widely distributed at 580 to $1651 \mathrm{~m}$ depth, with partial nucleotide sequences of the mitochondrial COI gene revealing extremely high genetic diversity (haplotype diversity: 0.98 to 1.00). In contrast, local populations of Alvinocaris dissimilis and A. longirostris, both of which have narrower bathymetric distributions, were characterised by low haplotype diversity (0.29 to 0.52 ). In the Okinawa Trough, Alvinocaris sp. only occurs at the Irabu Knoll, but this species also inhabits the Suiyo Seamount on the volcanic front of the Izu-Bonin Arc (Northwest Pacific). This undescribed species had relatively high haplotype diversity $(0.70$ to 0.82$)$, with no genetic differentiation between the 2 sites. Certain factors may allow this species to occur at both sites (e.g. a chemical environment derived from similar substratum), despite geological differences in hydrothermal circulation (i.e. a back-arc basin versus an arc volcanic front, respectively). The findings of this study indicate that (1) the wide geographical and bathymetrical distributional ranges of the vent shrimp species cause high genetic diversity associated with stable population connectivity and (2) certain environmental features (e.g. depth and substratum) and life-history traits (e.g. feeding habitat and larval characteristics) represent important formative factors in the connectivity of alvinocaridids in the Northwest Pacific.
\end{abstract}

KEY WORDS: Alvinocaridid shrimp · Biogeography $\cdot$ Connectivity $\cdot$ Genetic diversity

\section{INTRODUCTION}

Since the discovery of the first hydrothermal vent in 1977, many vents associated with chemosynthetic communities have been documented (e.g. Connelly et al. 2012). In deep-sea reducing environments within hydrothermal vent fields, faunal communities mainly consist of endemic species (Tunnicliffe \& Fowler 1996) that are supported by the primary production of chemoautotrophic bacteria (Corliss et al. 1979). Animals endemic to vent systems are expected to have a high dispersal ability to maintain gene flow among local populations (Tyler \& Young 2003), as their habitats, which were formed by volcanic activities along midocean ridge systems, in back-arc basins, and on offaxis submarine volcanoes, are unstable and patchily 
distributed (Holm \& Hennet 1992, Van Dover 2000). Consequently, dispersal and connectivity among vent sites have a significant role in both the population dynamics and evolution of species endemic to hydrothermal vent ecosystems. Understanding the formative factors of connectivity among deep-sea chemosynthetic communities may clarify the biogeographic mechanisms that lead to the establishment and development of endemic fauna. However, research on the connectivity of vent-endemic species remains limited in the West Pacific (Vrijenhoek 2010), despite the evolutionary importance of this region (Moalic et al. 2012). Comparative analyses of the vent fauna from this region with other oceanic regions may provide important information about the biogeographic history of deepsea chemosynthetic communities.

The caridean family Alvinocarididae is comprised of 28 described species belonging to 8 genera, which are known from chemosynthetic environments between depths of 252 and $4960 \mathrm{~m}$ in the world's oceans (Nye et al. 2012, Yahagi et al. 2014). Molecular evidence indicates that they were established during the late Cretaceous/Early Tertiary (Yang et al. 2013). In the Northwest Pacific, alvinocaridids have been reported in the hydrothermal vent fields of the Okinawa Trough, the Izu-Bonin Arc, and the Mariana Arc, as well as in cold seep areas in Sagami Bay and the South China Sea (Komai \& Segonzac 2005, Fujikura et al. 2008, Li 2015).

The Okinawa Trough is a back-arc basin located behind the Ryukyu trench-arc system, where the Philippine Sea Plate subducts beneath the Eurasian plate. The recent magmatism related to the rifting stage of the Okinawa Trough is considered to have begun $\sim 2$ million years ago (Kimura 1996). At least 8 hydrothermal vent fields associated with chemosynthetic communities have been discovered in the Okinawa Trough (Fujikura et al. 2008, Watanabe et al. 2010). These communities are distributed from approximately 600 to $1600 \mathrm{~m}$ depth in the central and southern parts of the trough, which extend about 800 $\mathrm{km}$ in length (Fujikura et al. 2008, Watanabe et al. 2010). Two vent sites, the Yoron Hole (Fukuba et al. 2015a) and the Irabu Knoll of the Yaeyama Central Graben (Fukuba et al. 2015b), were recently discovered, and little information is available about the fauna at these sites.

Alvinocaridid shrimps are dominant megafaunal invertebrates in vent fields in the Okinawa Trough, in addition to the galatheid crab Shinkaia crosnieri and Bathymodiolus mussels (Watanabe et al. 2010). To date, 4 alvinocaridid species have been reported in this area: Alvinocaris brevitelsonis, A. dissimilis,
A. longirostris, and Shinkaicaris leurokolos (Komai \& Segonzac 2005, Watanabe \& Kojima 2015). A. brevitelsonis and $A$. dissimilis were only collected from the Minami-Ensei Knoll (Komai \& Segonzac 2005). A. brevitelsonis was described based on a single specimen collected from this site (Komai \& Segonzac 2005), and has not been subsequently recorded. $A$. longirostris occurs in the vent fields of the North Knoll of the Iheya Ridge, Izena Hole, Hatoma Knoll, and Dai-yon (No. 4) Yonaguni Knoll, in addition to a cold seep area off Hatsushima in Sagami Bay (Fujikura et al. 1995, 2008, Kikuchi \& Ohta 1995, Watabe \& Miyake 2000, Ohta \& Kim 2001, Komai \& Segonzac 2005). Moreover, this species has been reported to be present at the Brothers Caldera in New Zealand and the Jiaolong Cold Seep I in northeastern South China (Webber 2004, Li 2015). This species might have a bathymetrically restricted distribution, as it has not been reported at vent sites shallower than $700 \mathrm{~m}$ depth, even when geographically close to deeper habitats (Komai \& Segonzac 2005). S. leurokolos is widespread, and is one of the representative species of the Okinawa Trough (Watanabe \& Kojima 2015). In the latest review on the distribution of alvinocaridid shrimp, 2 distributional range patterns were advocated; namely, local (single vent field) and regional ( $>3$ to 6 vent fields). The distributional ranges of most Pacific species were classified as the local type, whereas those of the Atlantic species were classified as the regional type (Lunina \& Vereshchaka 2014). However, the alvinocaridids of the Okinawa Trough seem to exhibit both local and regional distributional patterns. Thus, the factors that determine the geographical distribution and population connectivity of alvinocaridids require identification.

The present study aimed to reveal the distributional ranges and genetic population structure of 4 alvinocaridid species inhabiting the Okinawa Trough to understand connectivity and its formative factors. This study is the first to investigate population genetics of vent shrimps in the Northwest Pacific, facilitating comparison with the observed patterns on the MidAtlantic Ridge (MAR; Teixeira et al. 2011, 2012), Central Indian Ridge (CIR; Beedessee et al. 2013), and in the southwestern Pacific (SWP; Thaler et al. 2014).

\section{MATERIALS AND METHODS}

\section{Sampling}

Specimens were collected from 5 hydrothermal vent fields in the Okinawa Trough; namely, the 


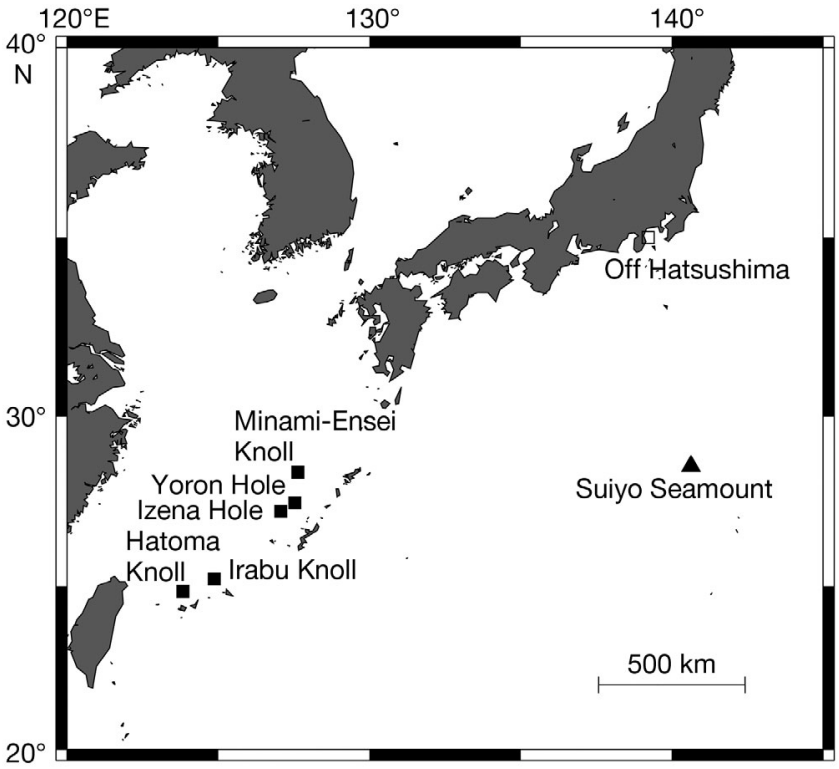

Fig. 1. Research locations in the Northwest Pacific. Black squares: vent fields in the Okinawa Trough; white square: a cold seep area in Sagami Bay; black triangle: seamount volcano in the Izu-Bonin Arc

Minami-Ensei Knoll (700 m depth), the Yoron Hole (580 $\mathrm{m}$ depth), the Izena Hole (1600 m depth), the Irabu Knoll (1650 m depth), and the Hatoma Knoll (1470 m depth) (Fig. 1). The remotely operated vehicle (ROV) 'Hyper-Dolphin' was equipped with a suction sampler to collect specimens during the cruise NT11-20 of the R/V 'Natsushima' of the Japan Agency for Marine-Earth Science and Technology (JAMSTEC) in September and October 2011. Additional specimens were collected from the Off Hatsushima site (930 m depth) in Sagami Bay and the Suiyo Seamount (1380 m depth) on the Izu-Bonin Arc using the ROV 'Hyper-Dolphin' during the NT11-09 cruise of the R/V 'Natsushima' in June 2011. Sampling and observations were conducted from the vicinity of vents to the peripheral area of each vent site. Collected specimens were frozen and stored at $-80^{\circ} \mathrm{C}$ or preserved in $99.5 \%$ ethanol. The specimens were identified, based on their morphology, using Komai \& Segonzac (2005) and Zelnio \& Hourdez (2009) as reference material.

\section{DNA sequencing}

All of the collected specimens were used for molecular analyses. Genomic DNA was extracted from the muscle of the abdomen using the DNeasy Tissue Extraction Kit (QIAGEN). A fragment con- taining part of the mitochondrial COI gene (658 bp) was amplified by polymerase chain reaction (PCR) using the LCO1490/HCO2198 universal primer set (Folmer et al. 1994). Amplification was performed in $20 \mu \mathrm{l}$ reaction mixture containing approximately $5 \mathrm{ng}$ genomic DNA, $2 \mu \mathrm{l} 10 \times \mathrm{Ex}$ Taq buffer, $0.3 \mu \mathrm{M}$ dNTP mix, $20 \mu \mathrm{M}$ of each primer, and $0.05 \mathrm{U}$ of EX Taq DNA polymerase (TaKaRa Bio Inc.). PCR reactions were carried out with an initial denaturation step at $94^{\circ} \mathrm{C}(40 \mathrm{~s})$, followed by 35 cycles consisting of a denaturation step at $94^{\circ} \mathrm{C}(40 \mathrm{~s})$, an annealing step at $50^{\circ} \mathrm{C}(60 \mathrm{~s})$, and an extension step at $72^{\circ} \mathrm{C}$ $(90 \mathrm{~s})$. The products were purified using Exo-SAP-IT (United States Biochemical). DNA sequences were determined using an ABI 3130 automated DNA sequencer (Applied Biosystems ${ }^{\circledR}$, Life Technologies Corporation) with a BigDye Terminator Cycle Sequencing Kit Version 3.1 (Applied Biosystems ${ }^{\circledR}$ ). Obtained sequences were edited and aligned using the computer program package MEGA 5.05 (Tamura et al. 2011), and were corrected by visual inspection.

\section{Population genetic and demographic analyses}

Genetic diversity was determined and statistical tests were conducted using the program package ARLEQUIN 3.5 (Excoffier \& Lischer 2010). We estimated haplotype diversity $h$ (Nei 1987), mean number of pairwise difference $\pi_{1}$ (Tajima 1983), and nucleotide diversity $\pi_{2}$ (Nei 1987) for each local population of the 4 species. For each species, a parsimonious haplotype network was constructed based on DNA sequences to represent gene genealogies using the computer program TCS 1.21 (Clement et al. 2000).

Significance of pairwise $F_{\mathrm{ST}}$-values (Hudson et al. 1992) was tested, and the exact test (Raymond \& Rousset 1995) was conducted to show the existence of genetic differentiation among local populations. In addition, Tajima's $D$-test (Tajima 1989), Fu's Fs-test (Fu 1997), and mismatch frequency distribution analysis (Rogers \& Harpending 1992) were performed using ARLEQUIN to test whether each population has experienced a recent population expansion (rapid increase of population size). The mismatch frequency distribution analysis (Rogers \& Harpending 1992) was calculated using Harpending's raggedness index (Hri; Harpending 1994). Local populations of Shinkaicaris leurokolos in the Minami-Ensei Knoll and Irabu Knoll were excluded in these analyses because of a limited number of specimens. 


\section{RESULTS}

\section{Distributional range of the 4 species}

The occurrence of the 4 alvinocaridid species in the Okinawa Trough is summarised in Table 1. None of the collected specimens could be identified as Alvinocaris brevitelsonis during the study. Alvinocaris sp. is an undescribed species that will be described elsewhere by R. Hiraoka, S. Tsuchida, and T. Komai (R. Hiraoka pers. comm.). Alvinocaris sp. was collected from 2 geographically separate locations: the Irabu Knoll in the Okinawa Trough and Suiyo Seamount in the Izu-Bonin Arc. The geographical distance between the 2 locations is approximately $1500 \mathrm{~km}$. At both locations, this species was mainly observed on volcanic rocks covered by bacterial mats and vent barnacles. A. dissimilis was only collected from the Minami-Ensei Knoll. This species inhabited Bathymodiolus mussel beds. A. longirostris was collected from the Irabu Knoll, in addition to its known habitats. Shinkaicaris leurokolos was collected from the Minami-Ensei Knoll, the Yoron Hole, the Izena Hole, the Irabu Knoll, and the Hatoma Knoll. A. longirostris and S. leurokolos exhibited different spatial distributions around the hydrothermal vent. Specifically, A. longirostris was distributed around Bathymodiolus mussel beds and colonies of Shinkaia crosnieri in the peripheral areas, whereas $S$. leurokolos was distributed in the part of the vent edifice closest to where the hydrothermal fluid reached (Fig. 2).

Table 1. Sampling locations and numbers of individuals collected per alvinocaridid shrimp species per location. Ad: Alvinocaris dissimilis; Al: A. longirostris; Asp: Alvinocaris sp.; Sl: Shinkaicaris leurokolos; -: not recorded for the location

\begin{tabular}{|lcrrrrrrr|}
\hline Sampling locations & \multicolumn{3}{c}{$\begin{array}{c}\text { Code } \\
\text { (m) }\end{array}$} & Ad & Al & Asp & Sl & \\
\hline Okinawa Trough & & & & & & & \\
Minami-Ensei Knoll & MK & 700 & 17 & - & - & 2 & 19 \\
Yoron Hole & YH & 580 & - & - & - & 17 & 17 \\
Izena Hole & IH & 1617 & - & 20 & - & 11 & 31 \\
Irabu Knoll & IK & 1651 & - & 20 & 19 & 3 & 42 \\
Hatoma Knoll & HK & 1477 & - & 19 & - & 20 & 39 \\
Sagami Bay & & & & & & & \\
Off Hatsushima (seep) & OH & 928 & - & 7 & - & - & 7 \\
Izu-Bonin Arc & & & & & & & \\
Suiyo Seamount & SS & 1387 & - & - & 19 & - & 19 \\
Total & & & 17 & 66 & 38 & 53 & 174 \\
& & & & & & & \\
\hline
\end{tabular}

\section{Population genetic analyses}

In total, 174 nucleotide sequences of the partial COI gene (658 bp) were read for the 4 vent shrimp species. A total of 77 haplotypes were deposited in DDBJ/EMBL/GenBank databases (Accession Numbers LC029809 to LC029885). The 4 species exhibited highly different genetic diversity (Table 2). $A$. dissimilis and A. longirostris exhibited low genetic diversity; Alvinocaris sp. had moderate diversity, and S. leurokolos showed extremely high diversity.

The haplotype network of $A$. dissimilis consisted of a common haplotype expressed by 14 individuals and the remaining haplotypes with 1 to 3 point mutations from the most common haplotype. The haplotype network of A. longirostris showed a starlike topology which consisted of a common haplotype expressed by 51 individuals and the remaining haplotypes with 1 to 4 point mutations from the most common haplotype (Fig. 3). The test of pairwise $F_{\mathrm{ST}}$-values and the exact test showed no significant genetic differentiation among the vent/seep local populations of $A$. longirostris (Table 3 ). The haplotype network of Alvinocaris sp. consisted of 2 most common haplotypes which did not depend on the geographic origin or the remaining haplotypes, with 1 - or 2-point mutations from the 2 most com-

Table 2. Genetic diversity based on the nucleotide sequences of the mitochondrial COI gene of alvinocaridids collected in the Northwest Pacific. N: number of specimens; $K$ : number of polymorphic sites; Nh: number of haplotypes; $h$ : haplotype diversity; $\pi_{1}$ : mean number of pairwise differences; $\pi_{2}$ : nucleotide diversity. Error values are \pm SD. For location codes, see Table 1

\begin{tabular}{|c|c|c|c|c|c|c|}
\hline \multicolumn{2}{|c|}{ Location $N$} & $K$ & $\mathrm{Nh}$ & $h$ & $\pi_{1}$ & $\pi_{2}\left(\times 10^{-2}\right)$ \\
\hline \multicolumn{7}{|c|}{ Alvinocaris dissimilis } \\
\hline MK & 17 & 4 & 4 & $0.33 \pm 0.14$ & $0.68 \pm 0.54$ & $0.10 \pm 0.09$ \\
\hline \multicolumn{7}{|c|}{ Alvinocaris longirostris } \\
\hline $\mathrm{IH}$ & 20 & 6 & 7 & $0.52 \pm 0.13$ & $0.60 \pm 0.50$ & $0.09 \pm 0.08$ \\
\hline IK & 20 & 4 & 5 & $0.39 \pm 0.14$ & $0.67 \pm 0.53$ & $0.10 \pm 0.09$ \\
\hline HK & 19 & 5 & 5 & $0.39 \pm 0.14$ & $0.53 \pm 0.46$ & $0.08 \pm 0.08$ \\
\hline $\mathrm{OH}$ & 7 & 1 & 2 & $0.29 \pm 0.20$ & $0.29 \pm 0.34$ & $0.04 \pm 0.06$ \\
\hline \multicolumn{7}{|c|}{ Alvinocaris sp. } \\
\hline IK & 19 & 11 & 10 & $0.82 \pm 0.08$ & $2.74 \pm 1.52$ & $0.42 \pm 0.26$ \\
\hline SS & 19 & 9 & 7 & $0.70 \pm 0.10$ & $2.16 \pm 1.25$ & $0.33 \pm 0.21$ \\
\hline \multicolumn{7}{|c|}{ Shinkaicaris leurokolos } \\
\hline MK & 2 & 5 & 2 & $1.00 \pm 0.50$ & $5.00 \pm 3.87$ & $0.76 \pm 0.83$ \\
\hline $\mathrm{YH}$ & 17 & 26 & 17 & $1.00 \pm 0.02$ & $4.88 \pm 2.50$ & $0.74 \pm 0.43$ \\
\hline $\mathrm{IH}$ & 11 & 25 & 10 & $0.98 \pm 0.05$ & $5.38 \pm 2.81$ & $0.82 \pm 0.48$ \\
\hline IK & 3 & 4 & 3 & $1.00 \pm 0.27$ & $2.67 \pm 1.92$ & $0.41 \pm 0.36$ \\
\hline HK & 20 & 24 & 18 & $0.99 \pm 0.02$ & $3.74 \pm 1.97$ & $0.57 \pm 0.33$ \\
\hline
\end{tabular}




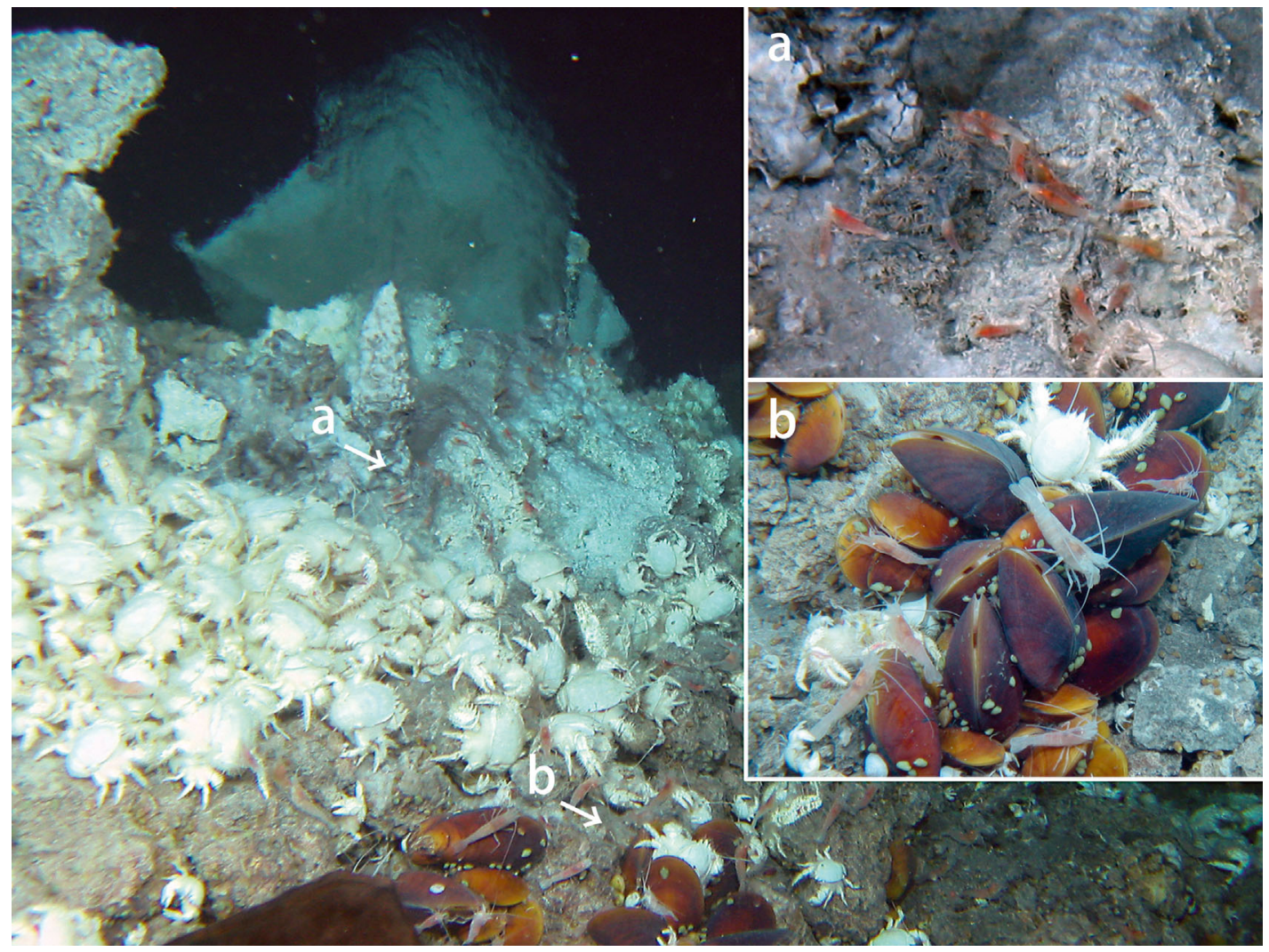

Fig. 2. Different spatial distributions of Shinkaicaris leurokolos and Alvinocaris longirostris around a hydrothermal vent: (a) S. leurokolos was distributed in the central areas where hydrothermal fluid was reached, whereas (b) A. longirostris was distributed in the peripheral areas around Bathymodiolus mussel beds or colonies of Shinkaia crosnieri

mon haplotypes (Fig. 3). The test of pairwise $F_{\mathrm{ST}^{-}}$ values and the exact test showed no significant genetic differentiation between the 2 local populations (IK and $\mathrm{SS}_{i} F_{\mathrm{ST}}=-0.0167$ ). Haplotype diversity values of $S$. leurokolos were at least 0.98 for all local populations. Compared to the other 3 species, the haplotype network of $S$. leurokolos was complicated (Fig. 3). The test of pairwise $F_{\mathrm{ST}}$-values and the exact test of $S$. leurokolos showed no significant genetic differentiation among local popula-

Table 3. Alvinocaris longirostris. Exact test (upper right) and pairwise $F_{\mathrm{ST}}$-values (lower left) based on haplotype frequencies. $F_{\mathrm{ST}}$-values were non-significant $(n s ; \mathrm{p}>0.05)$. For location codes, see Table 1

\begin{tabular}{|lrccc|}
\hline Location & IH & IK & HK & OH \\
\hline IH & & ns & ns & ns \\
IK & 0.0091 & & ns & ns \\
HK & -0.0960 & -0.0092 & & ns \\
OH & -0.0298 & -0.0047 & -0.0249 & \\
\hline
\end{tabular}

tions at Yoron Hole, Izena Hole, and Hatoma Knoll (Table 4).

The Hri-values were not significant in any population of the 4 species (Table 5). Tajima's $D$ - and Fu's $F$-tests showed significant negative values $(\mathrm{p}<0.05)$ for local populations of A. longirostris and S. leurokolos at the Izena Hole and Hatoma Knoll sites (Table 5). In addition, significant negative Fs-values were obtained for local populations of $A$. longirostris and Alvinocaris sp. at Irabu Knoll and of S. leurokolos at Yoron Hole (Table 5).

Table 4. Shinkaicaris leurokolos. Results of the exact test (upper right) and pairwise $F_{\mathrm{ST}}$-values (lower left) based on haplotype frequencies. $F_{\mathrm{ST}}$-values were non-significant (ns; $\mathrm{p}>0.05)$. For location codes, see Table 1

\begin{tabular}{|lccc|}
\hline Location & YH & IH & HK \\
\hline YH & & ns & ns \\
IH & -0.0231 & & ns \\
HK & 0.0267 & -0.0320 & \\
\hline
\end{tabular}



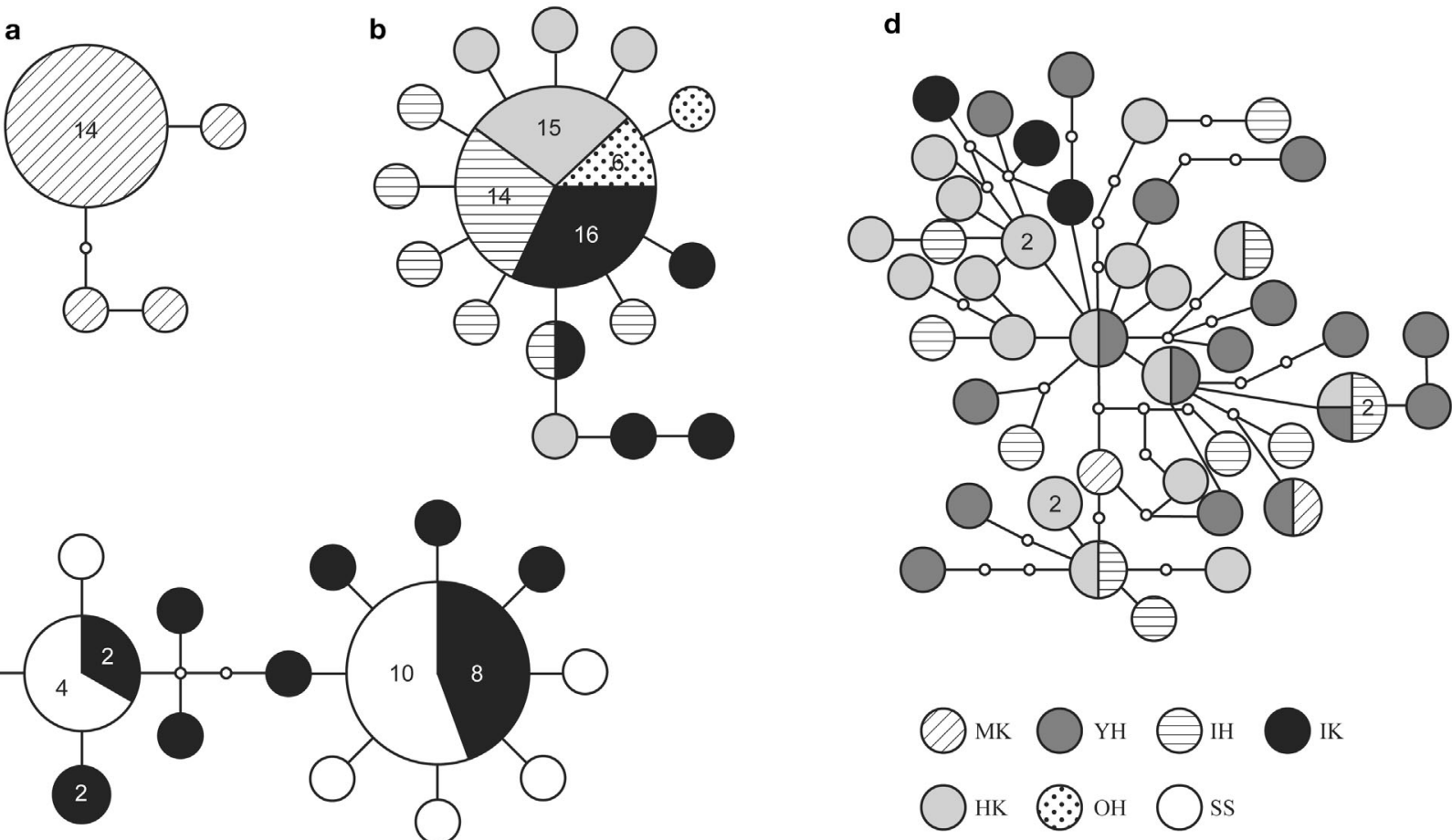

Fig. 3. Haplotype networks of (a) Alvinocaris dissimilis, (b) A. longirostris, (c) Alvinocaris sp., and (d) Shinkaicaris leurokolos based on the nucleotide sequences of the mitochondrial COI gene. Each circle represents a haplotype; its area is proportional to the frequency of the haplotype, and the sectors correspond to the sampling locations, with numbers indicating number of individuals with that haplotpye at that location (1 if not stated). Small white circles represent undiscovered haplotypes. Each line represents 1 mutational step. For location codes, see Table 1

\section{DISCUSSION}

\section{Distributional range of the 4 alvinocaridids}

In this study, the 4 alvinocaridid species inhabiting the Okinawa Trough partly showed bathymetric distribution patterns. However, Lunina \& Vereshchaka (2014) suggested that depth might not control the distribution of alvinocaridids significantly, based on the distributional information of 26 vent and coldseep endemic species of alvinocaridids. Komai \& Segonzac (2005) suggested bathymetrical separation between Alvinocaris longirostris and 2 other Alvinocaris species, $A$. brevitelsonis and $A$. dissimilis. Indeed, in this study, specimens of $A$. dissimilis were only collected from the Minami-Ensei Knoll at a depth of $700 \mathrm{~m}$. The absence of $A$. longirostris in the 2 shallow vent fields of the Minami-Ensei Knoll and the Yoron Hole (580 m depth) indicates that the distribution of this species is restricted to greater depths. The haplotype diversity of $A$. dissimilis and A. longirostris was low. In contrast, Shinkaicaris leurokolos had a wide bathymetric distribution range, spanning between 580 and $1651 \mathrm{~m}$ depth and showed high haplotype diversity. Furthermore, Alvinocaris sp. had
Table 5. Results of population expansion tests. D: Tajima's $D$-value; $\mathrm{p}(D)$ : p-value of Tajima's $D_{i} F_{S}$ : Fu's $F_{S}$-value; $\mathrm{p}\left(F_{S}\right)$ : $\mathrm{p}$-value of Fu's $F_{S} ; \tau$ : $\tau$-value of mismatch distribution; $\mathrm{p}(\mathrm{Hri})$ : p-value of Harpending's raggedness index. Values in bold type are significant $(p<0.05)$. For location codes, see Table 1

\begin{tabular}{|c|c|c|c|c|c|c|}
\hline Location & $D$ & $\mathrm{p}(D)$ & FS & $\mathrm{p}(F s)$ & $\tau$ & $\mathrm{p}(\mathrm{Hri})$ \\
\hline \multicolumn{7}{|c|}{ Alvinocaris dissimilis } \\
\hline MK & -1.31 & 0.08 & -1.06 & 0.10 & 3.00 & 0.56 \\
\hline \multicolumn{7}{|c|}{ Alvinocaris longirostris } \\
\hline $\mathrm{IH}$ & -2.06 & 0.01 & -5.66 & 0.00 & 0.73 & 0.52 \\
\hline IK & -1.18 & 0.26 & -2.18 & 0.02 & 3.00 & 0.52 \\
\hline HK & -1.97 & 0.00 & -2.91 & 0.00 & 1.02 & 0.85 \\
\hline $\mathrm{OH}$ & -1.01 & 0.25 & -0.09 & 0.22 & 2.98 & 0.65 \\
\hline \multicolumn{7}{|c|}{ Alvinocaris sp. } \\
\hline IK & -0.47 & 0.34 & -3.35 & 0.03 & 5.21 & 0.46 \\
\hline SS & -0.56 & 0.34 & -1.07 & 0.24 & 5.68 & 0.45 \\
\hline \multicolumn{7}{|c|}{ Shinkaicaris leurokolos } \\
\hline YH & -1.48 & 0.05 & -15.08 & 0.00 & 5.16 & 0.51 \\
\hline $\mathrm{IH}$ & -1.70 & 0.03 & -4.24 & 0.01 & 5.41 & 0.26 \\
\hline HK & -1.73 & 0.04 & -15.81 & 0.00 & 3.90 & 0.54 \\
\hline
\end{tabular}

an interesting geographical distribution pattern. This species is the first alvinocaridid that has been recorded in both the Okinawa Trough and Izu-Bonin Arc. In the Okinawa Trough, this species was only 
collected from the Irabu Knoll. Yet, it should have an extremely high dispersal ability, as no genetic differentiation was detected between the populations at the Okinawa Trough and Izu-Bonin Arc sites. Hydrothermal activity at Irabu Knoll is considered as hosted by basaltic magma (Watanabe et al. 2006). In fact, continuous exposures of fresh basaltic pillow lava were observed along a steep slope of the Irabu Knoll (Matsumoto et al. 2001). Among the 8 hydrothermal vent fields located in the Okinawa Trough, only Irabu Knoll shows evidence of basaltic magma activity on the seafloor, whereas the other fields are exposed to felsic magma (Ishibashi et al. 2015). In the Izu-Bonin arc, a magnetic survey indicated that the Suiyo Seamount is mainly composed of basaltic rocks (Fujiwara et al. 2007). Hydrothermal vents in the Lau back-arc basin of the SWP contain distinct fauna that are distributed according to the bottom substrate (basalt and andesite lava), which determines the chemical characteristics of hydrothermal vent fluids (Podowski et al. 2010, Kim \& Hammerstrom 2012). The Okinawa Trough and Izu-Bonin Arc have different geological settings, with the former being an arcback arc system and the latter a system of seamounts. However, the 2 sites share certain environmental factors (namely, the substratum and chemical composition of vent fluid), which might permit the establishment and distribution of this alvinocaridid species. Thus, the key factor determining the distribution of this species may be the environmental conditions of the habitat, rather than larval dispersal ability.

On the Hatoma Knoll, S. leurokolos and A. longirostris exhibited different microdistributions; $A$. longirostris was distributed at the base and periphery of the vent edifice and $S$. leurokolos aggregated in the hydrothermally active zones. When the 2 species were reared under atmospheric conditions, different optimum temperatures were required for the eggs of the 2 species to hatch, which indicates that these 2 species preferentially inhabit different thermal environments ( $\mathrm{H}$. Watanabe et al. unpubl. data). The microhabitat preferences of $S$. leurokolos are similar to those of Rimicaris exoculata, which is the dominant species on the MAR. $R$. exoculata, which has symbiotic relationships with epibiotic bacteria, feed on the symbiotic bacteria and free-living filamentous bacteria associated with chimney walls (Gebruk et al. 2000, Guri et al. 2012), while little is known about the feeding ecology of $S$. leurokolos. In contrast, Alvinocaris species feed on both bacteria and other animals, including Bathymodiolus mussels and barnacles inhabiting the base and periphery of the vent edifice (Gebruk et al. 2000, Stevens et al. 2008, Zel- nio \& Hourdez 2009). This difference in feeding preference may also determine the microhabitats in which they live. Studies of symbiotic associations, food sources, and the reproduction of alvinocaridids are required to understand the physiological characteristics of these species, as well as the mechanisms that regulate habitat segregation among species.

\section{Genetic diversity and population expansion}

The 4 species exhibited different levels of genetic diversity. The genetic diversity of Alvinocaris sp. was moderate, of $S$. leurokolos was high, and of A. dissimilis and $A$. longirostris was low. Both the frequency of long-distance dispersal and fluctuations in population size influence the genetic diversity of vent species (Vrijenhoek 1997). In particular, pioneer species that quickly colonise hydrothermal vents at the initial stages of formation tend to sustain higher genetic diversity than species that slowly establish colonies (Vrijenhoek 2010). In the present study, high haplotype diversity was observed for each local population of $S$. leurokolos (haplotype diversity: 0.98 to 1.00 ) and no genetic differentiation was detected among the local populations. S. leurokolos is assumed to have a high colonisation ability compared to the other 3 alvinocaridids because this species (1) is broadly distributed both spatially and bathymetrically and (2) rapidly colonised a newly developed hydrothermal vent site at Yoron Hole, where all of the collected chimneys and ores are $<400$ yr in age (Fujiwara et al. 2015). Another dominant decapod species in the Okinawa Trough, Shinkaia crosnieri, also has high genetic diversity (Kumagai et al. 2015). Shinkaia crosnieri and S. leurokolos share some ecological characteristics: namely, aggregation in areas that are directly affected by vent fluids and wide bathymetric ranges in the Okinawa Trough. Two species of Rimicaris shrimp, $R$. exoculata and $R$. kairei, also exhibit high haplotype diversity ( 0.69 to 0.89 ) in all local populations within their wide distributional range on the MAR and CIR, respectively (Teixeira et al. 2011, Beedessee et al. 2013). Moreover, a pair of synonymous species, A. muricola/markensis, which were suggested to exhibit connectivity across the Gulf of Mexico, the MAR, and West Africa, exhibit quite high haplotype diversity in each local population (0.80 to 0.91 ; Teixeira et al. 2013). Populations of an undescribed Chorocaris shrimp, which are distributed in both the Manus and North Fiji basins in the SWP, also exhibit high haplotype diversity ( 0.70 to 
1.00; Thaler et al. 2014). In contrast, local populations of $A$. dissimilis and A. longirostris, which have narrower bathymetric distributions (Table 1 ), are characterised by low haplotype diversity (0.29 to 0.52 ). The wide geographical and bathymetrical distributional ranges seem to cause high genetic diversity associated with stable population connectivity, with these factors being influenced by complex evolutionary processes (Hurtado et al. 2004).

The population expansion tests indicate that expansion has occurred in all 4 alvinocaridids, as the Hri-values were not significant. Recent population expansion was suggested to have occurred for each local population of vent shrimp on the MAR and CIR (Teixeira et al. 2011, 2013, Beedessee et al. 2013). Although detailed information about the fecundity and generation times of all 4 alvinocaridids are required to infer expansion ages accurately, higher $\tau$-values of the mismatch distribution correspond to older expansion ages (Harpending 1994). The populations of A. dissimilis and A. longirostris have expanded recently after a bottleneck or founder event ( $\tau: 0.73$ to 3.00 ). Such recent population growth is frequently found for vent organisms (Vrijenhoek 2010). In contrast, the populations of Alvinocaris sp. and $S$. leurokolos remain stable after expansion events at older ages ( $\tau$ : 3.90 to 5.68), which might lead to high genetic diversity. Pioneer species are expected to be highly tolerant to temporal and regional changes in hydrothermal activity, which might allow them to maintain local populations under inadequate conditions. Differences in the expansion ages between conspecific local communities might indicate unsynchronised hydrothermal activity in the Okinawa Trough.

\section{Genetic population structure}

Geographical barriers, ocean currents, and species life-history traits influence the genetic population structure of vent animals (Vrijenhoek 2010). Alvinocaridids exhibit high connectivity between distinct local populations on the MAR and CIR (Teixeira et al. 2011, 2013, Beedessee et al. 2013). In the present study, Alvinocaris sp. did not show genetic differentiation between the Okinawa Trough and the IzuBonin Arc either, suggesting stable connectivity over long distances. The Ryukyu Arc lies between the 2 sea areas, and might prevent the dispersal of the larvae of some species, such as Neoverruca barnacles (Watanabe et al. 2005). In fact, haplotypes were not shared between Neoverruca sp. populations in the
Okinawa Trough and Izu-Bonin Arc, whereas local populations within each area exhibited no significant genetic differences (Watanabe et al. 2005). The difference in genetic population structure between Alvinocaris sp. and Neoverruca sp. may be attributable to the 2 species having different modes of larval development. All known larvae of alvinocaridid shrimp are planktotrophic, which enable them to disperse over long distances (e.g. Ramirez-Llodra et al. 2000, Copley \& Young 2006, Ramirez-Llodra \& Segonzac 2006, Nye et al. 2013), whereas neoverrucid larvae are lecithotrophic (Watanabe et al. 2004). Under atmospheric pressure, the survival rate of neoverrucid larvae drastically decreases at temperatures $>15^{\circ} \mathrm{C}$, which corresponds to temperatures above the sill of the Ryukyu Arc (Watanabe et al. 2005). Although the temperature tolerance of the larvae of Alvinocaris sp. has not yet been examined, this species would need to exhibit higher tolerance to high water temperature than neoverrucid larvae to maintain high connectivity between the 2 sea areas. In addition, alvinocaridid larvae have eyes (RamirezLlodra et al. 2000, Miyake et al. 2007), while neoverrucid larvae lack eyes (Watanabe et al. 2004). This difference might indicate that alvinocaridid larvae adapt easily to the euphotic environment near the sea surface. Fatty acid biomarker and stable isotope analyses of small juvenile alvinocaridids indicate that individuals may use photosynthetic products during the pelagic larval phase (Gebruk et al. 2000, Stevens et al. 2008). Therefore, larval characteristics might represent one of several key factors determining population connectivity between the Okinawa Trough and the Izu-Bonin Arc.

A. longirostris showed no genetic differentiation among 3 vent sites in the Okinawa Trough (Hatoma Knoll, Izena Hole, and Irabu Knoll) and a seep site in Sagami Bay (the Off Hatsushima site). Similarly, no genetic differentiation was detected between local populations of alvinocaridids at seep sites in the Gulf of Mexico and West Africa, and the Logatchev vent field (Teixeira et al. 2013). These results indicate that differences between vent and seep environments are not primary factors in determining the geographical distribution and genetic population structure of certain alvinocaridids. Instead, these species may use different chemosynthetic environments as stepping stones for long-distance dispersal.

The present study revealed interspecific differences in the geographical distribution (local and regional type) and genetic population structure of 4 alvinocaridid shrimp species in the Okinawa Trough. Environmental parameters (such as depth and sub- 
stratum) and life-history traits (such as feeding habits and larval characteristics) may represent important formative factors of connectivity in this region. Additional information on oceanographic and geomorphic data and life-history traits (such as reproductive biology and larval ecology), as well as more detailed examinations of population structures using sufficient numbers of samples of $S$. leurokolos and additional DNA markers, are anticipated to provide a more detailed understanding about the biogeography and connectivity among chemosynthetic communities in the Northwest Pacific.

Acknowledgements. We are thankful to Dr. Tomoyuki Komai (Natural History Museum and Institute, Chiba) for providing scientific support with the taxonomy of alvinocaridids and Dr. Shinji Tsuchida (JAMSTEC) for providing help as an expert of the ecology of alvinocaridids. We are deeply grateful to the captain, officers, and crews of the R/V 'Natsushima' and the operation team of the ROV 'Hyper-Dolphin' for providing technical support, and Dr. Koji Inoue (University of Tokyo) for providing scientific support in collecting samples. This study was supported in part by the scientific research innovative area 'TAIGA', which is sponsored by the Ministry of Education, Culture, Sports, Science and Technology, Japan (No. 20109004).

\section{LITERATURE CITED}

Beedessee $\mathrm{G}$, Watanabe $\mathrm{H}$, Ogura $\mathrm{T}$, Nemoto $\mathrm{S}$ and others (2013) High connectivity of animal populations in deepsea hydrothermal vent fields in the Central Indian Ridge relevant to its geological setting. PLoS ONE 8:e81570

Clement M, Posada D, Crandall KA (2000) TCS: a computer program to estimate gene genealogies. Mol Ecol 9: 1657-1659

> Connelly DP, Copley JT, Murton BJ, Stansfield K and others (2012) Hydrothermal vent fields and chemosynthetic biota on the world's deepest seafloor spreading centre. Nat Commun 3:620

Copley JTP, Young CM (2006) Seasonality and zonation in the reproductive biology and population structure of the shrimp Alvinocaris stactphila (Caridea: Alvinocarididae) at a Louisiana Slope cold seep. Mar Ecol Prog Ser 315: 199-209

Corliss JB, Dymond J, Gordon LI, Edmond JM and others (1979) Submarine thermal springs on the Galápagos Rift. Science 203:1073-1083

> Excoffier L, Lischer HL (2010) Arlequin suite Ver. 3.5: a new series of programs to perform population genetics analyses under Linux and Windows. Mol Ecol Resour 10: 564-567

Folmer O, Black M, Hoeh W, Lutz R, Vrijenhoek R (1994) DNA primers for amplification of mitochondrial cytochrome $c$ oxidase subunit I from diverse metazoan invertebrates. Mol Mar Biol Biotechnol 3:294-299

Fu YX (1997) Statistical tests of neutrality of mutations against population growth, hitchhiking and background section. Genetics 147:915-925

Fujikura K, Hashimoto J, Fujiwara Y, Okutani T (1995)
Community ecology of the chemosynthetic community at Off Hatsushima site, Sagami Bay, Japan. JAMSTEC J Deep Sea Res 11:227-241 (in Japanese, with English summary)

Fujikura K, Okutani T, Maruyama T (eds) (2008) Deep-sea life-biological observations using research submersibles. Tokai University Press, Kanagawa (in Japanese with English figure captions)

Fujiwara T, Ishizuka O, Tamura Y, Geshi N, Shaw A, O Leary J, Tanaka H, Minamizawa S (2007) Magmatic and bathymetric survey of the Suiyo cross-chain, IzuBonin Arc. JAMSTEC Rep Res Dev 6: 31-38

Fujiwara T, Toyoda S, Uchida A, Ishibashi J, Nakai S, Takamasa A (2015) ESR dating of barite in sea-floor hydrothermal sulfide deposits in the Okinawa Trough. In: Ishibashi J, Okino K, Sunamura M (eds) Subseafloor biosphere linked to global hydrothermal system; TAIGA concept. Springer, Dordrecht, p 369-386

Fukuba T, Noguchi T, Fujii T (2015a) The Yoron Hole: the shallowest hydrothermal system in the Okinawa Trough. In: Ishibashi J, Okino K, Sunamura M (eds) Subseafloor biosphere linked to global hydrothermal system; TAIGA concept. Springer, Dordrecht, p 489-492

Fukuba T, Noguchi T, Fujii T (2015b) The Irabu Knoll: hydrothermal site at the eastern edge of the Yaeyama Graben. In: Ishibashi J, Okino K, Sunamura M (eds) Subseafloor biosphere linked to global hydrothermal system; TAIGA concept. Springer, Dordrecht, p 493-504

Gebruk AV, Southward EC, Kennedy H, Southward AJ (2000) Food sources, behavior, and distribution of hydrothermal vent shrimps at the Mid-Atlantic Ridge. J Mar Biol Assoc UK 80:485-499

> Guri M, Durand L, Cueff-Gauchard V, Zbinden M, Crassous P, Shillito B, Cambon-Bonavita MA (2012) Acquisition of epibiotic bacteria along the life cycle of the hydrothermal shrimp Rimicaris exoculata. ISME J 6:597-609

Harpending HC (1994) Signature of ancient population growth in a low resolution mitochondrial DNA mismatch distribution. Hum Biol 66:591-600

Holm NG, Hennet RJC (1992) Hydrothermal systems: their varieties, dynamics, and suitability for prebiotic chemistry. In: Holm NG (ed) Marine hydrothermal systems and the origin of life. Kluwer Academic Publishers, Dordrecht, p 15-31

$>$ Hudson RR, Slatkin M, Maddison WP (1992) Estimation of levels of gene flow from DNA sequence data. Genetics 132:583-589

> Hurtado LA, Lutz RA, Vrijenhoek RC (2004) Distinct patterns of genetic differentiation among annelids of eastern Pacific hydrothermal vents. Mol Ecol 13:2603-2615

Ishibashi J, Ikegami F, Tsuji T, Urabe T (2015) Hydrothermal activity in the Okinawa Trough Back-Arc Basin: geological background and hydrothermal mineralization. In: Ishibashi J, Okino K, Sunamura M (eds) Subseafloor biosphere linked to global hydrothermal system; TAIGA concept. Springer, Dordrecht, p 337-356

Kikuchi T, Ohta S (1995) Two caridean shrimps of the families Bresiliidae and Hippolytidae from a hydrothermal field on the Iheya Ridge, off the Ryukyu Islands, Japan. J Crustac Biol 15:771-785

> Kim S, Hammerstrom K (2012) Hydrothermal vent community zonation along environmental gradients at the Lau back-arc spreading center. Deep-Sea Res I 62:10-19

Kimura M (1996) Active rift system in the Okinawa Trough and its northeastern continuation. Bull Disas Prev Res 
Inst Kyoto Univ 45:27-38

Komai T, Segonzac M (2005) A revision of the genus Alvinocaris Williams and Chace (Crustacea: Decapoda: Caridea: Alvinocarididae), with descriptions of a new genus and a new species of Alvinocaris. J Nat Hist 39: 1111-1175

Kumagai H, Watanabe H, Yahagi T, Kojima S, Nakai S, Toyoda S, Ishibashi J (2015) Evaluating hydrothermal system evolution using geochronological gating and biological diversity analyses. In: Ishibashi J, Okino K, Sunamura M (eds) Subseafloor biosphere linked to global hydrothermal system; TAIGA concept. Springer, Dordrecht, p 49-59

Li X (2015) Report on two deep-water caridean shrimp species (Crustacea: Decapoda: Caridea: Alvinocarididae, Acanthephyridae) from the northeastern South China Sea. Zootaxa 3911:130-138

Lunina AA, Vereshchaka AL (2014) Distribution of hydrothermal alvinocaridid shrimps: effect of geomorphology and specialization to extreme biotopes. PLoS ONE 9: e92802

Matsumoto T, Kinoshita M, Nakamura M, Sibuet JC and others (2001) Volcanic and hydrothermal activities and possible 'segmentation' of the axial rifting in the westernmost part of the Okinawa Trough - preliminary results from the YOKOSUKA/SHINKAI 6500 Lequios Cruise. JAMSTEC J Deep Sea Res 19:95-107

> Miyake H, Kitada M, Tsuchida S, Okuyama Y, Nakamura K (2007) Ecological aspects of hydrothermal vent animals in captivity at atmospheric pressure. Mar Ecol (Berl) 28: 86-92

Moalic Y, Desbruyères D, Duarte CM, Rozenfeld AF, Bachraty C, Arnaud-Haond S (2012) Biogeography revisited with network theory: retracing the history of hydrothermal vent communities. Syst Biol 61:127-137

Nei M (1987) Molecular evolutionary genetics. Columbia University Press, New York, NY

> Nye V, Copley J, Plouviez S (2012) A new species of Rimicaris (Crustacea: Decapoda: Caridea: Alvinocarididae) from hydrothermal vent fields on the Mid-Cayman Spreading Centre, Caribbean. J Mar Biol Assoc UK 92: 1057-1072

> Nye V, Copley JT, Tyler PA (2013) Spatial variation in the population structure and reproductive biology of Rimicaris hybisae (Caridea: Alvinocarididae) at hydrothermal vents on the Mid-Cayman Spreading Centre. PLoS ONE 8:e60319

> Ohta S, Kim D (2001) Submersible observations of the hydrothermal vent communities on the Iheya Ridge, Mid Okinawa Trough, Japan. J Oceanogr 57:663-677

- Podowski EL, Ma S, Luther GW III, Wardrop D, Fisher CR (2010) Biotic and abiotic factors affecting distributions of megafauna in diffuse flow on andesite and basalt along the eastern Lau Spreading Center, Tonga. Mar Ecol Prog Ser 418:25-45

> Ramirez-Llodra E, Segonzac M (2006) Reproductive biology of Alvinocaris muricola (Decapoda: Caridea: Alvinocarididae) from cold seeps in the Congo Basin. J Mar Biol Assoc UK 86:1347-1356

Ramirez-Llodra E, Tyler PA, Copley JTP (2000) Reproductive biology of three caridean shrimp, Rimicaris exoculata, Chorocaris chacei and Mirocaris fortunata (Caridea: Decapoda), from hydrothermal vents. J Mar Biol Assoc UK 80:473-484

Raymond M, Rousset F (1995) An exact test for population differentiation. Evolution 49:1280-1283

> Rogers AR, Harpending H (1992) Population growth makes waves in the distribution of pairwise genetic differences. Mol Biol Evol 9:552-569

> Stevens CJ, Limén H, Pond DW, Gélinas Y, Juniper SK (2008) Ontogenetic shifts in the trophic ecology of two alvinocaridid shrimp species at hydrothermal vents on the Mariana Arc, western Pacific Ocean. Mar Ecol Prog Ser 356:225-237

> Tajima F (1983) Evolutionary relationships of DNA sequences in finite populations. Genetics 105:437-460

> Tajima F (1989) Statistical method for testing the neutral mutation hypothesis by DNA polymorphism. Genetics 123:585-595

> Tamura K, Peterson D, Peterson N, Stecher G, Nei M, Kumer S (2011) MEGA5: molecular evolutionary genetics analysis using maximum likelihood, evolutionary distance, and maximum parsimony methods. Mol Biol Evol 28: 2731-2739

> Teixeira S, Cambon-Bonavita MA, Serrão EA, Desbruyéres D, Arnaud-Haond S (2011) Recent population expansion and connectivity in the hydrothermal shrimp Rimicaris exoculata along the Mid-Atlantic Ridge. J Biogeogr 38: 564-574

> Teixeira S, Serrão EA, Arnaud-Haond S (2012) Panmixia in a fragmented and unstable environment: the hydrothermal shrimp Rimicaris exoculata disperses extensively along the Mid-Atlantic Ridge. PLoS ONE 7:e38521

Teixeira S, Olu K, Decker C, Cunha RL and others (2013) High connectivity across the fragmented chemosynthetic ecosystems of the deep Atlantic Equatorial Belt: efficient dispersal mechanisms or questionable endemism? Mol Ecol 22:4663-4680

Thaler AD, Plouviez S, Saleu W, Alei F and others (2014) Comparative population structure of two deep-sea hydrothermal-vent-associated decapods (Chorocaris sp. 2 and Munidopsis lauensis) from southwestern Pacific back-arc basins. PLoS ONE 9:e101345

Tunnicliffe V, Fowler CMR (1996) Influence of sea-floor spreading on the global hydrothermal vent fauna. Nature 379:531-533

- Tyler PA, Young CM (2003) Dispersal at hydrothermal vents: a summary of recent progress. Hydrobiologia 503:9-19

Van Dover CL (2000) The ecology of deep-sea hydrothermal vents. Princeton University Press, Princeton, NJ

> Vrijenhoek RC (1997) Gene flow and genetic diversity in naturally fragmented metapopulations of deep-sea hydrothermal vent animals. J Hered 88:285-293

Vrijenhoek RC (2010) Genetic diversity and connectivity of deep-sea hydrothermal vent metapopulations. Mol Ecol 19:4391-4411

Watabe H, Miyake H (2000) Decapod fauna of the hydrothermally active and adjacent fields on the Hatoma Knoll, southern Japan. JAMSTEC J Deep Sea Res 17: 29-34 (In Japanese with English abstract)

Watanabe H, Kojima S (2015) Vent fauna in the Okinawa Trough. In: Ishibashi J, Okino K, Sunamura M (eds) Subseafloor biosphere linked to global hydrothermal system; TAIGA concept. Springer, Dordrecht, p 449-459

> Watanabe H, Kado R, Tsuchida S, Miyake H, Kyo M, Kojima $S$ (2004) Larval development and intermoult period of the hydrothermal vent barnacle Neoverruca sp. J Mar Biol Assoc UK 84:743-745

- Watanabe H, Tsuchida S, Fujikura K, Yamamoto H, Inagaki F, Kyo M, Kojima S (2005) Population history associated 
with hydrothermal vent activity inferred from genetic structure of neoverrucid barnacles around Japan. Mar Ecol Prog Ser 288:233-240

Watanabe M, Hoshino K, Shiokawa R, Takaoka Y and others (2006) Metallic mineralization associated with pillow basalts in the Yaeyama Central Graben, Southern Okinawa Trough, Japan. JAMSTEC Rep Res Dev 3:1-8

Watanabe H, Fujikura K, Kojima S, Miyazaki JI, Fujiwara Y (2010) Japan: vents and seeps in close proximity. In: Kiel $\mathrm{S}$ (ed) The vent and seep biota: aspects from microbes to ecosystems. Topics in Geobiology, Vol 33. Springer, Dordrecht, p 379-401

Webber WR (2004) A new species of Alvinocaris (Crustacea: Decapoda: Alvinocarididae) and new records of alvinocaridids from hydrothermal vents north of New Zealand.

Editorial responsibility: Karen Miller, Hobart, TAS, Australia
Zootaxa 444:1-26

Yahagi T, Watanabe H, Kojima S, Beedessee G, Komai T (2014) First record and a new species of Alvinocaris Williams \& Chace, 1982 (Crustacea: Decapoda: Caridea: Alvinocarididae) from the Indian Ocean. Zootaxa 3893: 101-113

> Yang JS, Lu B, Chen DF, Yu YQ and others (2013) When did decapods invade hydrothermal vents? Clues from the western Pacific and Indian Oceans. Mol Biol Evol 30: 305-309

Zelnio KA, Hourdez S (2009) A new species of Alvinocaris (Crustacea: Decapoda: Caridea: Alvinocarididae) from hydrothermal vents at the Lau Basin, southwest Pacific, and a key to the species of Alvinocarididae. Proc Biol Soc Wash 122:52-71

Submitted: November 3, 2014; Accepted: March 4, 2015

Proofs received from author(s): May 18, 2015 